\title{
Real-time PCR-based study of haemotrophic mycoplasmas in dogs from Ribeirão Preto, Brazil
}

\author{
Estudio de micoplasmas hemotróficos en perros de Ribeirão Preto, Brasil, \\ basado en la PCR en tiempo real
}

\author{
TB Alves ${ }^{\mathrm{a}}$, SA Faggion ${ }^{\mathrm{a}}$, EV Santos ${ }^{\mathrm{a}}$, PG Roberto ${ }^{\mathrm{a}}$, SC França ${ }^{\mathrm{a}}$, AL Fachin ${ }^{\mathrm{a}}$, M Marins ${ }^{\mathrm{a}, \mathrm{b}^{*}}$ \\ ${ }^{a}$ Unidade de Biotecnologia, Universidade de Ribeirão Preto, Ribeirão Preto, Brazil.

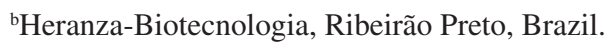

\begin{abstract}
RESUMEN
Mycoplasma haemocanis y Candidatus Mycoplasma haematoparvum son hemoparásitos caninos asociados a la anemia en perros. La garrapata Rhipicephalus sanguineus está indicada como el principal vector de transmisión, pero una clara asociación de la exposición de canes a garrapatas e infección no fue establecida. El objetivo de este estudio fue la aplicación de la PCR en tiempo real para estudiar la prevalencia de haemoplasmas en perros de la ciudad brasileña de Ribeirão Preto, donde $R$. sanguineus es un vector común para hemoparásitos, tales como Ehrlichia canis y Babesia canis. ADN de Mycoplasma haemocanis fue detectado en 3 perros y de Candidatus Mycoplasma haematoparvum en 1 perro, entre 154 analizados, indicando una baja prevalencia de esos hemoparásitos.
\end{abstract}

Palabras clave: Candidatus Mycoplasma haemocanis, Mycoplasma haemocanis, PCR en tiempo real.

\section{SUMMARY}

Mycoplasma haemocanis and Candidatus Mycoplasma haematoparvum are canine haemoparasites associated with anemia in dogs. The tick Rhipicephalus sanguineus has been pointed as the main vector of transmission, but a clear association between the exposure of dogs to ticks and infection has not been established. The aim of this study was to apply real-time PCR to study the prevalence of haemoplasmas in dogs from the Brazilian town of Ribeirão Preto, where R. sanguineus is a common vector for other haemoparasites such as Ehrlichia canis and Babesia canis. DNA of Mycoplasma haemocanis was detected in 3 and Candidatus Mycoplasma haematoparvum in 1 out of 154 tested dogs, indicating a low prevalence of these hemoparasites.

Key words: Candidatus Mycoplasma haemocanis, Mycoplasma haemocanis; real-time PCR.

\section{INTRODUCTION}

The genus Mycoplasma (Mollicutes order) forms a group of bacteria which are obligate parasites of several species of animals and are associated with anemia, arthritis, infertility and respiratory disorders (Chalker 2005, Willi et al 2007). Generically called mycoplasmas, they have a very small genome and are devoid of a cell wall. Among the pathogenic species, the hemotrophic mycoplasmas (haemoplasmas) are receiving more attention in recent years due to increased infections in human patients, especially those with compromised immune systems (Santos et al 2008). They are characterised by parasitism of the surface of erythrocytes of different mammalian species in which they cause anemia with variable intensity, from asymptomatic cases to the potentially fatal (Chalker 2005, Willi et al 2007).

Accepted: 03.10.2013.

* marins@heranza.com.br
M. haemocanis, previously Haemobartonella canis, and Candidatus M. hematoparvum are associated with anemia in dogs (canine hemoplasmosis), but the establishment of more severe clinical cases seem to be dependent on other factors including immune status, co-infection and splenectomy (Chalker 2005). The prevalence in dogs is considered low; however, the use of more sensitive methods of detection may change this picture. The infection of animals that may or may not develop clinical signs of disease, with varying degrees of severity has been descrbed worldwide (Kenny et al 2004, Roura et al 2010, Sykes et al 2004, Wengi et al 2008, Novacco et al 2010). The tick Rhipicephalus sanguineus has been pointed as transmission vector (Messick 2003), but a clear association of dog exposure to ticks and infection has not been established. Other modes of transmission would be by oral ingestion and passage from mother to fetus via the placenta (Krakowka 1977). R. sanguineus has wide distribution in tropical countries and is the vector of several other hemoparasites of veterinary importance such as 
the bacterium Ehrlichia canis, causative agent of canine ehrlichiosis, and the protozoan Babesia canis, causative agent of canine babesiosis (Dantas-Torres 2008). These two diseases are quite common in dogs in Brazil and thrombocytopenia is a common laboratory finding after infection by these parasites, which also occurs in infections with M. haemocanis (Kemming et al 2004, Sykes et al 2004). In addition, co-infection with these parasites, followed by a state of immunosuppression, can lead to more severe hemoplasmosis (Chalker 2005).

Due to the specific culture requirements, which have not yet been fully established, the identification of mycoplasmas is based on clinical signs and visualization in blood smears, using the methods of Romanowsky staining or acridine orange. Although they should not be excluded, cytological methods have low sensitivity and specificity to establish a precise diagnosis for clear association with clinical symptoms.

More recently, some techniques based on DNA amplification are becoming an alternative for the detection and identification of parasites in veterinary practice. In this regard, the detection of haemoplasmas using the polymerase chain reaction (PCR) is currently considered the most accurate technique (Willi et al 2007). Conventional and quantitative real-time PCR assays based on the amplification of $16 \mathrm{~S}$ ribosomal RNA genes are among the most commonly used to differentiate between species (Sykes et al 2007, Willi et al 2007, Wengi et al 2008, Gentilini et al 2009, Santos et al 2009, Barker et al 2010). The development of cheaper and less complex procedures associated with these techniques will facilitate their large-scale application in veterinary laboratories.

The aim of this study was to conduct a molecular survey and characterisation of M. haemocanis and Candidatus .M. haemocanis in dogs from Ribeirão Preto, Brazil, a country with increasing population of pet dogs, high incidence of $R$. sanguineus in rural and urban areas and still with few data available about canine haemoplasmas.

\section{MATERIAL AND METHODS}

\section{CLINICAL SAMPLES AND DNA EXTRACTION}

EDTA-anticoagulated blood samples from $154 \mathrm{dogs}$ presenting to a private veterinary clinic were collected throughout a one year period between August 2009 and July 2010. DNA was extracted from $200 \mathrm{ml}$ blood using the Illustra blood Miniprep kit (GE Health care).

\section{REAL-TIME PCR}

The samples were analysed by a published Real Time PCR assay using primers and TaqMan probes targeted to the $16 \mathrm{~S}$ ribosomal RNA gene of M. haemocanis and Candidatus. M. haematoparvum (Barker et al 2010). Positive control reactions were performed with primers and TaqMan probe targeted to the canine gene GAPDH (Canine) and for each combination of primers and probes a negative reaction was also performed using sterilized water instead of DNA. Basically each reaction tube contained a general solution of $12.5 \mu \mathrm{L}$ 1X Master Mix (Roche Real time PCR Mix), $0.5 \mu \mathrm{L}$ of each primer (200 $\mathrm{nM}), 0.5 \mu \mathrm{L}$ TaqMan probe (100 nM), $10 \mu \mathrm{L}$ DNA (0.5$1.0 \mathrm{ug}$ ), and sterile pure water in a final volume of $15 \mu \mathrm{L}$. After a brief centrifugation tubes were taken to the thermal cycler (Stratagene MXp3500P) where they were incubated under the following conditions: $95{ }^{\circ} \mathrm{C}$ for $15 \mathrm{~min}$ followed by 45 cycles with a first step of $95{ }^{\circ} \mathrm{C}$ for $15 \mathrm{~s}$ and a second step of $60{ }^{\circ} \mathrm{C}$ for $60 \mathrm{~s}$. In the second step the fluorescence data was collected.

\section{DETECTION THRESHOLD OF THE REAL-TIME PCR ASSAY}

The detection threshold of the assay was evaluated using plasmid containing a cloned fragment of the target genes obtained by conventional PCR. After measuring the plasmid DNA concentrations with the Genequant 1300 system (GE Healthcare, USA), the corresponding copy numbers were calculated. The plasmids were diluted to contain $10^{5}$ copies/ $\mu \mathrm{L}$ and 10-fold serial dilutions were then prepared. One microliter was used in each reaction mixture for evaluation of the detection threshold of the assay which could detect a minimum of 10 copies of the plasmid.

\section{HEMI-NESTED PCR}

Positive samples in real-time PCR were subjected to conventional hemi-nested PCR using primers directed to the $16 \mathrm{~S}$ rDNA of these species. In the first reaction, forward primer MHCFWD1 5' TCGAACGGACCTTGGTTTCGGCC 3' and MHCREV1 5' TCCTATCCGAACTGAGACGAA $3^{\prime}$ were used to generate a fragment of 1187 bps encompassing position 1 to 1187 of the $M$. haemocanis gene, based in the reference sequence EF416568. For amplification of the Candidatus M. haematoparvum, primers CMHFWD1 5' GGAGAATAGCAATCCGAAAGG 3' and CMHREV2 5' CAGCCCGAGGCATAAGGGGC 3'were used to generate a fragment of 1062 bps encompassing position 110 to 1171 , based in the reference sequence EF416569. In the second reaction, primers MHCFWD2 5'- GCAAGCGCAGGCGGATGTG 3' and MHCREV1 were used to generate a fragment of $705 \mathrm{bps}$ encompassing position 483 to 1187 of the M. haemocanis reference sequence. For Candidatus M. haematoparvum, primers CMHFWD1 and CMHREV2 5' CCACGCTTTCAAGCCTCAGCGT 3'were used to generate a fragment of 635 bps encompassing position 110 to 744, based in the reference sequence. For the first PCR, a general solution was prepared containing the reagents in sufficient amounts for each reaction tube to contain $400 \mathrm{nM}$ of each primer, $200 \mathrm{mM}$ of dNTPs, $1.8 \mathrm{mM}$ magnesium chloride, 
1X PCR buffer (100 mM Tris HCl, pH 8.5, and $500 \mathrm{mM}$ $\mathrm{KCl}$ ), 1.5 units Taq polymerase (LGCBio), and sterile pure water in a final volume of $25 \mu \mathrm{L}$. A $10-\mu \mathrm{L}$ aliquot of purified DNA (0.5-1.0 $\mu \mathrm{g})$ was added to each tube. In the second PCR reaction, the same general solution but a $1-\mu \mathrm{L}$ aliquot of the first reaction was used as template. In both reactions, sterile water replaced DNA in negative control reactions. The tubes were brought to the thermocycler (Bioer) and incubated with the following times and temperatures: $95{ }^{\circ} \mathrm{C}$ for 5 min followed by 35 cycles with three steps of $95{ }^{\circ} \mathrm{C}$ for $30 \mathrm{~s}, 60{ }^{\circ} \mathrm{C}$ for $30 \mathrm{~s}$ and $72{ }^{\circ} \mathrm{C}$ for $60 \mathrm{~s}$. The reactions were completed with a final step of $72{ }^{\circ} \mathrm{C}$ for $10 \mathrm{~min}$ and stored at $10{ }^{\circ} \mathrm{C}$. PCR products were checked by agarose gel electrophoresis, stained with ethidium bromide and visualized under ultraviolet light. Positive nested PCR products were purified using the Illustra GFX PCR DNA and Gel Band Purification kit (GE Healthcare) and cloned with the PCR Cloning kit (Qiagen) following the protocols of the manufacturers. After cloning the plasmid containing the fragments of interest were extracted and purified with aid of Plasmid Miniprep GeneJET kit (Fermentas). After checking the clones with inserts by DNA enzyme digestion, they were submitted to automatic DNA sequencing using a MegaBace 1000 DNA Analysis System (GE Healthcare). Sequence identity was checked by similarity search with the BLASTN software (Altschul et al 1990). A published PCR protocol was also used for detection of Ehrlichia canis and Babesia canis in order to compare infection with Mycoplasma species (Santos et al 2009).

\section{RESULTS AND DISCUSSION}

In Ribeirão Preto, the prevalence of canine haemoplasmas was considered low. Among the 154 dogs tested, M. haemocanis DNA was detected in 3 dogs (1.9\%) and Candidatus M. haematoparvum DNA in $1(0.6 \%)$. Coinfection of both hemoplasma species was not detected. In Brazil, $R$. sanguineus is the vector for two other canine hemoparasites, the Gram-negative bacteria Ehrlichia canis which cause the canine monocytic ehrlichiosis agent, and Babesia canis, the canine babesiosis agent. Among the 154 samples tested, 32 were positive for $E$. canis DNA (20.7\%) and 5 were positive for B. canis DNA (3.2\%). Co-infection with these parasites, which have considerable prevalence in Brazil, and canine haemoplasmas were also not detected. The PCR fragments of 16S rRNA gene of the canine haemoplasma isolates were cloned and sequenced (GeneBank HQ918287, HQ918288). Similarity search with the BLASTN program showed $99 \%$ similarity to corresponding M. haemocanis (EF416568) and Candidatus M. haematoparvum (EF416569) published sequences. $R$. sanguineus is pointed as the biological transmission vector of canine haemoplasmas and studies conducted in Europe indicate a correlation between the presence of $R$. sanguineus and infection of dogs. For example, a study conducted in Switzerland, where R. sanguineus is not common, indicated rare infection of dogs by hemoplasma (Wengi et al 2008) while in France, where the tick is common, a $3.3 \%$ and $9.6 \%$ rate of infection was found for M. haemocanis and C.M. hematoparvum, respectively (Kenny et al 2004). In Brazil, R. sanguineus has a wide distribution and is the most important canine tick in urban areas (Labruna and Pereira 2001). Studies conducted with conventional PCR detected infection of dogs by canine haemoplasmas but with variable rates of prevalence in different regions of the country. In Belo Horizonte, a town with a tropical climate located in the southeast region of Brazil, M. haemocanis prevalence varied between 5.8\% (6/104) for dogs living in urban areas to $11.3 \%$ (20/176) for dogs in rural areas (Biondo et al 2009). In Londrina, located in the south region and with a subtropical climate, prevalence of M. haemocanis was of $1.4 \%(2 / 147)$ (Biondo et al 2009). Ribeirão Preto is also located in the southeast, $522 \mathrm{~km}$ far from Belo Horizonte and $491 \mathrm{~km}$ from Londrina, and presents a tropical climate. Using real-time PCR, we found a $1.9 \%$ (3/154) prevalence for M. haemocanis and 0,6\% (1/154) for C.M. haemoatoparvum. Until now, detection of C.M. hematoparvum was only described for Londrina, with $7.5 \%$ (11/147) prevalence. Remarkably, while the isolate described in this study showed 99\% similarity to published sequences of C.M. haematoparvum, after DNA sequencing the detected isolates from Londrina were found to be more similar to M. haemocanis than to C.M. hematoparvum (Biondo et al 2009). The low number of hemoplasma infection found in the dogs of Ribeirão Preto does not allow a safe correlation between infection and gender, age, race or clinical signs. A possible explanation for this low infection could be a low exposition of the studied canine population to $R$. sanguineus but though the dogs infected by the two studied haemoplasmas species were not co-infected by $E$. canis or B. canis, $21 \%$ of the samples were positive for $E$. canis DNA, indicating that the population is exposed to the tick vector. Moreover, the studies conducted in other Brazilian towns also do not indicate these associations. We conclude that, at least in Brazil, it is still not possible to establish the risk factors for infection, including regional climate variation and presence of the potential vector $R$. sanguineus. Therefore, the impact of haemoplasmas in canine health needs further study. The application of molecular assays would help by improving veterinary diagnosis. With the increasing world dog population, these assays should be applied more often to monitor canine haemoplasmas and other hemoparasites in order to keep a healthy population of dogs.

\section{REFERENCES}

Altschul SF, W Gish, W Miller, EW Myers, DJ Lipman. 1990. Basic local alignment search tool. J Mol Biol 215, 403410. 
Barker EN, S Tasker, MJ Day, SM Warman, K Woolley, R Birtles, KC Georges, CD Ezeokoli, A Newaj-Fyzul, MD Campbell, OAE Sparagano, S Cleaveland, CR Helps. 2010. Development and use of real-time PCR to detect and quantify Mycoplasma haemocanis and "Candidatus Mycoplasma haematoparvum" in dogs. Vet Microbiol 140, 167-170.

Biondo AW, AP Dos Santos, AM Guimaraes, RF Vieira, O Vidotto, B Macieira Dde, NR Almosny, MB Molento, J Timenetsky, HA de Morais, FH Gonzalez, JB Messick. 2009. A review of the occurrence of haemoplasmas (hemotrophic mycoplasmas) in Brazil. Rev Bras Parasitol Vet $18,1-7$.

Chalker VJ. 2005. Canine mycoplasmas. Res Vet Sci 79, 1-8.

Dantas-Torres F. 2008. The brown dog tick, Rhipicephalus sanguineus (Latreille, 1806) (Acari: Ixodidae): from taxonomy to control. Vet Parasitol 152, 173-185.

Gentilini F, M Novacco, ME Turba, B Willi, ML Bacci, R Hofmann-Lehmann. 2009. Use of combined conventional and real-time PCR to determine the epidemiology of feline haemoplasma infections in northern Italy. J Feline Med Surg 11, 277-285.

Kemming GI, JB Messick, G Enders, M Boros, B Lorenz, S Muenzing, H Kisch-Wedel, W Mueller, A HahmannMueller, K Messmer, E Thein. 2004. Mycoplasma haemocanis infection - a kennel disease? Comparative Med 54, 404-409.

Kenny MJ, SE Shaw, F Beugnet, S Tasker. 2004. Demonstration of two distinct hemotropic mycoplasmas in French dogs. J Clinical Microbiol 42, 5397-5399.

Krakowka S. 1977. Transplacentally acquired microbial and parasitic diseases of dogs. J Am Vet Med Assoc 171, 750753.

Labruna MB, MC Pereira. 2001. Carrapatos em cães no Brasil. Clin Vet 30, 24-32.

Messick JB. 2003. New perspectives about Hemotrophic mycoplasma (formerly, Haemobartonella and Eperythrozoon species) infections in dogs and cats. Vet Clin N Am-Small 33, 1453-1465.

Novacco M, ML Meli, F Gentilini, F Marsilio, C Ceci, MG Pennisi, G Lombardo, A Lloret, L Santos, T Carrapico, B Willi, G Wolf, H Lutz, R Hofmann-Lehmann. 2010. Prevalence and geographical distribution of canine hemo- tropic mycoplasma infections in Mediterranean countries and analysis of risk factors for infection. Vet Microbiol 142, 276-284.

Roura X, IR Peters, L Altet, MD Tabar, EN Barker, M Planellas, CR Helps, O Francino, SE Shaw, S Tasker. 2010. Prevalence of hemotropic mycoplasmas in healthy and unhealthy cats and dogs in Spain. J Vet Diagn Invest 22, 270-274.

Santos AP, RP dos Santos, AW Biondo, JM Dora, LZ Goldani, ST de Oliveira, AM de Sa Guimaraes, J Timenetsky, HA de Morais, FH Gonzalez, JB Messick. 2008. Hemoplasma infection in HIV-positive patient, Brazil. Emerg Infect Dis 14, 1922-1924.

Santos AP, JB Messick, AW Biondo, ST Oliveira, V Pedralli, CS Lasta, LA Lacerda, VS Esteves, R Hofmann-Lehmann, B Willi, FH Gonzalez. 2009. Design, optimization, and application of a conventional PCR assay with an internal control for detection of 'Candidatus Mycoplasma turicensis' 16S rDNA in domestic cats from Brazil. Veterinary Clin Pathol 38, 443-452.

Santos F, JS Coppede, AL Pereira, LP Oliveira, PG Roberto, RB Benedetti, LB Zucoloto, F Lucas, L Sobreira, M Marins. 2009. Molecular evaluation of the incidence of Ehrlichia canis, Anaplasma platys and Babesia spp. in dogs from Ribeirao Preto, Brazil. Vet J 179, 145-148.

Sykes JE, NL Bailiff, LM Ball, O Foreman, JW George, MM Fry. 2004. Identification of a novel hemotropic mycoplasma in a splenectomized dog with hemic neoplasia. J Am Vet Med Assoc 224, 1946-1951.

Sykes JE, NL Drazenovich, LM Ball, CM Leutenegger. 2007. Use of conventional and real-time polymerase chain reaction to determine the epidemiology of hemoplasma infections in anemic and nonanemic cats. J Vet Intern Med 21, 685-693.

Wengi N, B Willi, FS Boretti, V Cattori, B Riond, ML Meli, CE Reusch, H Lutz, R Hofmann-Lehmann. 2008. Real-time PCR-based prevalence study, infection follow-up and molecular characterisation of canine hemotropic mycoplasmas. Vet Microbiol 126, 132-141.

Willi B, FS Boretti, S Tasker, ML Meli, N Wengi, CE Reusch, H Lutz, R Hofmann-Lehmann. 2007. From Haemobartonella to hemoplasma: molecular methods provide new insights. Vet Microbiol 125, 197-209. 